\title{
STRATEGI PEMASARAN DALAM ALQURAN TENTANG PROMOSI PENJUALAN
}

\author{
Rizki Syahputra \\ Sekolah Tinggi Ilmu Ekonomi (STIE) Labuhan Batu, Sumatera Utara
}

\begin{abstract}
Abstraks
Setiap bisnis tentunya mempunyai tujuan tertentu, misalnya meraih laba, mempertahankan eksistensi, mencapai pertumbuhan tertentu, merebut pangsa pasar, memberi pelayanan sosial dan lain-lain. Promosi merupakan salahsatu bagian dari rangkaian kegiatan pemasaran suatu barang. Tujuan promosi adalah untuk mempengaruhi suatu konsumen dalam mengambil keputusan untuk meningkatkan volume penjualan. Dalam tulisan ini kita hanya membatasi pada surat al-Baqarah ayat 2. Jelas bahwa ayat ke 2 pertama pada surat al-Baqarah bisa jadi selama ini dipahami tidak memiliki keterkaitan dengan bisnis, ternyata kandungannya memiliki kedekatan makna dengan apa yang berlaku di dalam dunia bisnis.
\end{abstract}

\section{Kata kunci : Pemasaran, Promosi, al-Baqarah}

A. Pendahuluan

Setiap bisnis tentunya mempunyai tujuan tertentu, misalnya meraih laba, mempertahankan eksistensi, mencapai pertumbuhan tertentu, merebut pangsa pasar, memberi pelayanan sosial dan lain-lain. Untuk mencapai tujuan tersebut, pebisnis berupaya menghasilkan suatu produk yang kemudian ditawarkan kepada pasar. Produk bisa berupa barang dan jasa.

Promosi merupakan salahsatu bagian dari rangkaian kegiatan pemasaran suatu barang. Promosi adalah suatu kegiatan bidang marketing yang merupakan komunikasi yang dilaksanakan pebisnis kepada pembeli atau konsumen yang memuat pemberitaan, membujuk, dan mempengaruhi segala sesuatu mengenai barang maupun jasa yang di hasilkan untuk konsumen.

Tujuan promosi adalah untuk mempengaruhi suatu konsumen dalam mengambil keputusan untuk meningkatkan volume penjualan. Dalam promosi kita tidak hanya sekedar berkomunikasi ataupun menyampaikan informasi, tetapi juga menginginkan komunikasi yang mampu menciptakan suasana atau keadaan dimana para konsumen bersedia memilih dan memiliki produk. 
Dalam tulisan ini akan kita bahas mengenai strategi Allah dalam mempromosi penjualan, bagaimana Allah berkomunikasi sehingga mempengaruhi bagi siapa yang membaca produk-Nya yaitu Alquran.

Dalam tulisan ini kita hanya membatasi pada surat al-Baqarah ayat 2 . Dengan tulisan ini kita dapat melihat kemukzijatan Alquran yang memang terus sesuai dengan perkembangan zaman.

\section{B. Definisi}

Strategi diartikan sebagai cetak biru, desain, muslihat, program, rencana, siasat, skema, kebijakan, pendekatan, politik, garis haluan dan prosedur. Sedangkan secara istilah, strategi diartikan sebagai perencanaan dan pengaturan operasional untuk mencapai suatu tujuan tertentu.

Pengertian strategi pemasaran adalah upaya memasarkan suatu produk, baik itu barang atau jasa, dengan menggunakan pola rencana dan taktik tertentu sehingga jumlah penjualan menjadi lebih tinggi.strategi pemasaran juga dapat diartikan sebagai rangkaian upaya yang dilakukan oleh perusahaan dalam rangka mencapai tujuan tertentu, karena potensi untuk menjual proposisi terbatas pada jumlah orang yang mengetahui hal tersebut.

Strategi Pemasaran punya peranan penting dalam sebuah perusahaan atau bisnis karena berfungsi untuk menentukan nilai ekonomi perusahaan, baik itu harga barang maupun jasa. Ada tiga faktor penentu nilai harga barang dan jasa, yaitu:

- Produksi

- Pemasaran

- Konsumsi

Pengertian Promosi adalah suatu akitivitas komunikasi yang dilakukan oleh seseorang atau suatu perusahaan dengan masyarakat luas, dimana tujuannya adalah untuk memperkenalkan sesuatu (barang/ jasa/ merek/ perusahaan) kepada masyarakat dan sekaligus mempengaruhi masyarakat luas agar membeli dan menggunakan produk tersebut

Promosi menurut kothler adalah kegiatan yang dilakukan oleh perusahaan yang menonjolkan keistimewaan-keistimewaan produknya yang membujuk konsumen sasaran agar membeli. Mengacu pada pengertian promosi di atas tujuan promosi pada umumnya secara keseluruhan melakukan promosi adalah agar meningkatkan angka penjualan dan keuntungan usaha. 
a. Pembahasan

Di atas sudah kita sebutkan bahwa ayat yang akan kita ambil untuk menerangkan strategi pemasaran dalam mempromosi penjualan pada surat Albaqarah ayat 2. Surat alBaqarah turun di Madinah, kecuali ayat 281 yang turun di Mina waktu haji Wada' (haji yang terakhir dikerjakan Rasulullah s.a.w.). Jumlah ayat-ayat Surat Al Baqarah ini 286 ayat. Surat al-Baqarah ialah Surat yang paling panjang dari Alquran. Ayat 282 dari Surat Al Baqarah adalah ayat yang terpanjang. Ayat ini menerangkan soal hutang-piutang atau ayat kemasyarakatan.Surat al-Baqarah mulai menguraikan kesimpulan dari Surat Al Faatihah. Surat ini dinamakan "al-Baqarah" (Sapi betina) karena di dalamnya disebutkan kisah sapi betina itu.

Keistimewaan surat al-Baqarah sebagaimana Imam Turmuzi meriwayatkan melalui hadis dari Abu Hurairah r.a. yang menceritakan bahwa Rasulullah Saw. pernah bersabda: "Segala sesuatu itu mempunyai punuk (puncak)nya tersendiri, sedangkan punuk AlQuran adalah surat al-Baqarah. Di dalamnya terkandung penghulu ayat-ayat Al-Qur'an, yaitu ayat Kursi." Dan juga Di dalam kitab Musnad Imam Ahmad, Sahih Muslim, Sunan Turmuzi, dan Sunan Nasai disebutkan melalui hadis Suhail ibnu Abu Saleh, dari ayahnya, dari Abu Hurairah r.a., bahwa Rasulullah Saw. pernah bersabda: “janganlah kalian jadikan rumah-rumah kalian seperti kuburan. karena sesungguhnya rumah yang di dalamnya dibacakan surat Al-Baqarah tidak akan kemasukan setan."

Mari kita lihat firman Allah surat al-Baqarah ayat 2

“ Kitab (Al Quran) ini tidak ada keraguan padanya; petunjuk bagi mereka yang bertaqwa".

Berkaitan dengan ayat ini pakar tafsir Alquran M. Quraish Shihab (2008; 50) berkata:

Anda dapat berkata bahwa ayat ini "mempromosikan Alquran". Allah menyatakan sebagai kitab sempurna, Dia menjamin kebenarannya, jaminan yang serupa dengan apa-apa yang oleh pebisnis dinamai dengan reliability product guarantee sambil menyebut manfaatnya sebahai hudan (petunuk) dan menyebut pula siapa yang dapat memanfaatkannya. Bukankah ini serupa dengan apa yang dilakukan para pebisnis ? atau dapat juuga dikatakan hahwa ini adalah pengajaran kepada setiap yang berminat 
melakukan jual beli, baik jasa, maupun barang untuk menempuh hal serupa dalam melakukan bisnisnya.

Azhari akmal Tarigan $(2014 ; 69)$ menyatakan: “Jelas bahwa ayat pertama pada QS alBaqarah di atas yang bisa jadi selama ini dipahami tidak memiliki keterkaitan dengan bisnis, ternyata kandungannya memiliki kedekatan makna dengan apa yang berlaku di dalam dunia bisnis. Bukankan sebuah promosi itu penting untuk menyakinkan konsumen atau pelanggan akan sebuah produk yang kita tawarkan. Bukankah setiap perusahaan harus merogoh uangnya dalam jumlah yang besar hanya untuk sebuah promosi. Sebuah aktivitas untuk menyakinkan pembeli sebuah produk".

Dalam berbisnis tentunya kita wajib memberitahu kepada pihak konsumen apa bentuk dari produk kita baik itu barang ataupun jasa, jadi pada kalimat pertama menuujukkan bahwa Allah memberikan informasi kepada pendengar sebagai fokus pemasaran pada saat itu satu produk bernama al-kitab yaitu nama lain dari Alquran.

Kewajiban yang harus dilakukan oleh pebisnis setelah memperkenalkan produk tentunya agar konsumen lebih yakin lagi yaitu dengan memberi power of trust berupa garansi. Pada kalimat ini Allah memberikan satu keyakinan bagi konsumennya yaitu para pendengar produknya Alquran dengan memberi garansi sampai kiamat bahwa Alquran tidak ada keraguan di dalamnya.

Jadi ini sangatlah relevan dengan kondisi bisnis di zaman yang serba canggih, informasi yang sangat mudah di dapat dan dibaca, tentunya pemberian garansi bagi suatu profuk merupakan suatu yang harus dilaksanakan agar konsumen tidak beralih tangan ke produk pengganti lainnya.

Tidak sampai disitu saja, kehebatan Allah untuk menyakinkan konsumennya pada saat itu dengan memberi tahu manfaat dari produknya Alquran, sehingga sangat jelas dan tidak akan pernah rugi bagi siapa pun yang memilikinya.

Pada kalimat terakhir pada ayat kedua Allah memberi gambaran kepada kita, kalau anda ingin berbisnis maka anda harus juga tentukan siapa konsumennya. Dan memang dalam strategi bisnis sangat harus diperhatikan jenis konsumen, bahkan sebenarnya kita harus memilih ciri-ciri konsumen dahulu baru menentukan produk apa yang akan kita jual. 
didalam Al-Qur'an juga dijelaskan banyak sekali teknik promosi produk yang baik yang dijelaskna secara baik dan sempurna seperti:

- Ketika membaca Al-Qur'an kita akan merasakan ketenangan dan kemulian dari Allah. didalam dunia bisnis melakukan promosi tidak boleh menjatuhkan produk pesaing sehingga didalam bisnis ada konsep etika yang dijunjung tinggi dan memuliakan orang lain lebih baik dari pada menjatuhkan orang lain.

- Diangkat derajatnya ( lebih dikenal Allah). Promosi yang masif dan dilakuakan terus menerus akan mengakibatkan dikenalnya sutu produk oleh masyarakat.

Strategi promosi yang baik akan membuat produk akan semakin terkenal sehingga akan menambah nilai dari produk yang dipasarkan dan juga menambah volume penjualan Barang.

b. Kesimpulan

Dari ayat di atas bisa kita urutkan satu persatu kalimat taktik bisnis yang di ajarkan langsung oleh Allah dalam surat al-Baqarah

1. Kalimat (ذاللك الكتاب) adalah produk, dan produk yang baik harusbisa memuaskan sebuah keinginan atau kebutuhan sipemakainya

2. Kalimat (لاريب فيه) adalah garansi, Garansi atau lazim pula disebut warranty adalah surat keterangan dari suatu produk bahwa pihak produsen menjamin produk tersebut bebas dari kesalahan pekerja dan kegagalan bahan dalam jangka waktu tertentu.

3. Kalimat (هدى) adalah manfaat. Maksudnya yaitu, setiap baran yang diperdagangkan harus memiliki manfaat yang jelas dan berkelanjutan

4. Kalimat (للمتقين) adalah yang menjadi konsumen, Maksudnya setiap orang pemakai barang dan/atau jasa yang tersedia dalam masyarakat, baik bagi kepentingan diri sendiri, keluarga, orang lain, maupun makhluk hidup lain dan tidak untuk diperdagangkan. 


\section{Daftar Bacaan}

M. Quraish Shihab, 2008, berbisnis dengan Allah:tips jitu jadi pebisnis sukses dunia-akhirat, Jakarta: lentera Hati

Azhari Akmal Tarigan,2014, Teologi Ekonomi,Jakarta: Rajawali Press

Phlip kothler \& amstrong. 2014, Prinsip-Prinsip Manajemen, edisi 14, jilid I. Jakarta: Erlangga 